\title{
A MULTIDIMENSIONAL MODEL OF POLICE LEGITIMACY: A CROSS-CULTURAL ASSESSMENT
}

\author{
JUSTICE TANKEBE \\ Institute of Criminology \\ University of Cambridge \\ MICHAEL D. REISIG \\ School of Criminology and Criminal Justice \\ Arizona State University \\ XIA WANG \\ School of Criminology and Criminal Justice \\ Arizona State University
}

* Direct correspondence to Justice Tankebe, Institute of Criminology, University of Cambridge, Sidgwick Avenue, Cambridge CB3 9DA, U.K. (email: jt340@cam.ac.uk). 


\begin{abstract}
This study used survey data from cross-sectional, university-based samples of young adults in different cultural settings (i.e., the United States and Ghana) to accomplish two main objectives: (1) construct a 4-dimensional police legitimacy scale, and (2) assess the relationship that police legitimacy and feelings of obligation to obey the police have with two outcome measures. The fit statistics for the second-order confirmatory factor models indicated that the 4-dimensional police legitimacy model is reasonably consistent with the data in both samples. Results from the linear regression analyses showed that the police legitimacy scale is related to cooperation with the police, and that the observed association is attenuated when the obligation to obey scale is included in the model specification in both the US and Ghana data. A similar pattern emerged in the US sample when estimating compliance with the law models. However, although police legitimacy was associated with compliance in the Ghana sample, this relationship along with the test statistic for the sense of obligation to obey estimate were both null in the fully saturated equation. The findings provide support for the Bottoms and Tankebe's (2012) argument legitimacy is a multi-dimensional, comprising police lawfulness, distributive fairness, procedural fairness, and effectiveness. However, the link between police legitimacy and social order appears to be culturally variable.
\end{abstract}

Keywords: legitimacy, cooperation, lawfulness, procedural fairness, compliance 


\section{A Multidimensional Model of Police Legitimacy: A Cross-Cultural Assessment}

Central to human social existence is the establishment, the application, and by consequence the violation of rules (Fortes, 1983). It follows that understanding the mechanisms or conditions that facilitate social order is a salient objective in the behavioral and social sciences. Toward this end, Bottoms (2002) has identified four mechanisms: habit, instrumental/prudential (or criminal deterrence), structural constraints, and normative compliance. This study concerns a subcategory of normative compliance-legitimacy. Until relatively recently, legitimacy was at the periphery of crime and justice research (Bottoms, 2002; Tankebe, 2014). The impetus for the change is credited to Tyler's (1990) seminal study, wherein it was shown that legitimacy exercised a direct and independent influence on legal compliance. Or, put differently, people who felt that legal authorities (e.g., the police) treated them unfairly were more likely to question the legitimacy of the law and criminal justice officials, which in turn adversely affected their willingness to comply with laws, regulations, and ordinances.

Following Tyler's (1990) work, a number of empirical studies emerged on the correlates and consequences of legitimacy perceptions across a variety of contexts. Most studies report findings in support of Tyler's two key findings: first, procedural justice (i.e., judgments about the fairness of the processes by which people are treated) is a strong correlate of legitimacy; and second, legitimacy enhances the likelihood of legal compliance and of people's willingness to cooperate with criminal justice authorities (Murphy \& Cherney, 2012a; Reisig, Tankebe, \& Meško, 2014; Hertogh, 2015). Other studies have shown that procedural justice and legitimacy influence support for vigilante violence, the use of violence for self-protection, and to achieve political goals (Jackson, Huq, Bradford, \& Tyler, 2013; Tankebe, 2009b; Tyler \& Jackson, 2014). 
Given the evidence on the importance of legitimacy for social order, questions about how best to conceptualize and to measure legitimacy are critical. Tyler (1990) originally operationalized legitimacy as two components: people's general sense of obligation to obey the law and their support for legal authorities (i.e., police and courts). Subsequent studies have used a variety of instruments. Some studies measure legitimacy using only obligation to obey the law (and the police) scales (Kochel, Parks, \& Mastrofski, 2011; Reisig \& Lloyd, 2009), others have combined obligation to obey with trust/confidence in legal authorities (Murphy \& Cherney, 2012b; Reisig, Bratton, \& Gertz, 2007), and still others have added moral alignment (i.e., the extent to which citizens and legal officials share common goals and values) to the measures just mentioned (Jackson et al., 2012; Tyler \& Jackson, 2014).

Some legitimacy researchers dispute these conceptual and operational approaches (Gau, 2011; Reisig et al., 2007; Tankebe, 2009a). And due to the inconsistencies in the measurement of legitimacy, some researchers even argue that it is impossible to draw conclusions about the relationship between legitimacy and compliance with the law (Eisner \& Nivette, 2013). For Bottoms and Tankebe (2012) whether trust, confidence, support for authorities, or a sense of obligation to obey are employed separately or in some combined form, none of it effectively captures legitimacy. They counsel crime and justice researchers to abandon the conventional approach and to chart a different course. Bottoms and Tankebe advance a multidimensional model of police legitimacy, and argue that people's feelings of obligation to obey and support for legal authorities are dependent variables to be explained, in part, by legitimacy. 


\section{The Bottoms-Tankebe Police Legitimacy Model}

Legitimate power is "power which is acknowledged as rightful by relevant agents, who include power-holders and their staff, those subject to the power and third parties whose support or recognition may help to confirm it" (Beetham, 2013, p. 19, emphasis in original). A merit of this definition is its emphasis on rightness, which reflects the inherently social nature of legitimacy; "rights are socially ordained, and an actor has a right to act, rule, or govern only if it is socially sanctioned. Similarly, when we say that an institution is rightful, and hence legitimate, we are saying that its norms, rules, and principles are socially endorsed" (Reus-Smit, 2007, p. 159). One of Beetham's (1991) major contributions is his clarification that political rightfulness comprises three elements (i.e., legality, shared values, and consent). Bottoms and Tankebe (2012) develop this meaning in the context of criminal justice.

The starting point for Bottoms and Tankebe (2012) is that legitimacy is best viewed as a continuous dialogue between power-holders and their audiences, with the former (e.g., police officers) making claims, the latter (e.g., citizens) responding, power-holders then perhaps adjusting their claims, and so on. It is through this iterative claim-response process that criminal justice agencies and their audiences come to a shared understanding about what legitimate power means. Because dialogues can take different forms in different cultural contexts, the meaning of rightful power can differ across societies (Tankebe, 2013a). Yet Bottoms and Tankebe argue that, within democratic societies, rightful power is power that embodies four elements.

The first element of the Bottoms-Tankebe legitimacy model is police lawfulness. The key consideration here concerns the source of power and whether the way in which it is exercised during typical police encounters conforms to established rules in particular societies. In other words, the lawfulness dimension entails policing under the rule of law; police officers should not 
be seen as making the law, but rather as enforcing the law as currently valid, and doing so within the boundaries of the law (Bottoms \& Tankebe, 2012; Tankebe, 2013a). Take, for example, public perceptions that police officers regularly stage the killing of crime suspects (Belur, 2010; Jauregui, 2013), frequently use illegal interrogation techniques (Leo, 2008), or routinely collect bribes from suspects (Punch, 1985). These unlawful activities inhibit the construction, maintenance, and reproduction of legitimate power. However, perceptions of lawfulness alone are insufficient to establish legitimacy. Bottoms and Tankebe identify three additional values that form part of the construction of the rightness of power.

The second element is distributive fairness, which reflects whether outcomes or the allocation of police resources are fair among groups or individuals with competing claims or needs (Roemer, 1996). There are two types of resources: concrete and symbolic resources (Lerner \& Clayton, 2011). Concrete resources are easily observable and quantifiable, symbolic resources are not. In the context of criminal justice, concrete resources may include court fines, tickets for traffic offenses, and police personnel, while symbolic resources include respect, courtesy, and dignity. Lerner and Clayton argue that distributive justice involves the acquisition and distribution of both sets of resources. Thus, an investigation into police distributive justice seeks to understand how fairly police allocate these resources across different social groups (as between rich/poor, different ethnic groups, or male/female). The argument is that part of the construction of rightness of police power is that officers should avoid discrimination in the allocation of resources or in the outcomes that people receive.

Procedural fairness is the third element in the Bottoms-Tankebe police legitimacy model. This describes the fairness of the processes employed to reach specific outcomes or decisions (Tyler, 1990). Tyler found that people are often more concerned about symbolic resources, such as 
respect, dignity, and recognition, during their everyday encounters with the police and the courts. Various empirical studies have shown that there are two aspects to procedural justice: quality of decision-making (which relates to judgments of police honesty, provision of opportunities for representation, opportunities for error correction, and whether legal authorities have behaved impartially); and, quality of interpersonal treatment (which concerns whether police have treated people with respect, dignity, and courtesy; see Reisig et al., 2007; Sunshine \& Tyler, 2003). To the casual observer, such issues may seem superficial and inconsequential, but they communicate information to citizens about their standing and membership in society. In short, everyday police-citizen encounters provide "teachable moments" that can build or undermine individual perceptions of police legitimacy (Tyler, 2011, p. 257).

Most prior police legitimacy studies treat police effectiveness as an instrumental concern that is not constitutive of legitimacy. For Bottoms and Tankebe (2012), effectiveness is an integral aspect of what makes power rightful. They argue for a distinction between police use of incentives to encourage cooperation and obedience (e.g., rewards for information about serious offenders) and the claim that part of what it means for legal authorities to establish and maintain rightful power is for them to be seen as responding to the security and safety needs of citizens. The former consideration is purely instrumental, the latter is not. So, when the public demands that the police demonstrate their effectiveness at reducing crime and related problems, they are expressing a normative condition that must be met for their legitimacy (Tankebe, 2013a).

Bottoms and Tankebe (2012) posit that traditional antecedents of legitimacy_judgments regarding lawfulness, procedural fairness, distributive fairness, and police effectiveness — are actually constitutive elements. They view obligation to obey as a mechanism through which legitimacy partially influences cooperation and compliance (see Figure 1). The model also 
allows for legitimacy to exert a direct influence on the two criterion variables. Tankebe's (2013a) London study not only established the construct validity of the Bottoms-Tankebe legitimacy model, it also showed police legitimacy influenced cooperation. After controlling for one's sense of obligation to obey, the direct effect of legitimacy on cooperation was attenuated by more than half (also see Hough, Jackson, \& Bradford, 2013).

[Insert Figure 1 about here]

\section{The Current Study in Context}

The objective of this study is to construct a 4-dimensional police legitimacy scale, and to assess the relationship that police legitimacy and feelings of obligation to obey the police have with cooperation with police and compliance with the law using data from two different cultural settings - the US and Ghana. Although the two countries share a common history as former British colonies, they represent two very different social, political, and legal contexts.

The US is a mature democracy, with over 200 years of democratic governance. Since the inception of the first uniform police force, reformers and police professionals have endeavored to insulate policing from local politics (see Reisig, 2010). US residents do not, however, view their police as free from corruption. According to the 2013 Global Corruption Barometer, on a scale ranging from 1 (not at all corrupt) to 5 (extremely corrupt), the US received a score of 3.3, which is similar to the United Kingdom (3.0) and South Korea (3.2; Hardoon \& Heinrich, 2013). A sizable portion of the US population appears to trust their local police. In 2011, for example, an estimated 31.4 million US residents called the police to request assistance. Of these individuals, 86.4\% said that the "police were helpful," 91.3\% reported that the police "acted properly," and $84.7 \%$ indicated they were "satisfied with police response" (Durose \& Langton, 2013). The 
Ghanaian context provides an interesting cultural juxtaposition to the US, especially with regards to police behavior and how they are viewed by the citizenry.

The recent political history of Ghana involves military interventions that truncated initial efforts at multi-party democratic governance (Ayittey, 1992). For example, from 1957 to 1992, Ghana experienced five military incursions in politics. Although there is evidence suggesting consistent gains in democratic consolidation, perceptions of political corruption are widespread (Gyimah-Boadi \& Brobbey, 2013). The Ghana police are widely perceived as the most corrupt public institution and distrusted by many Ghanaians (Afrobarometer, 2014). Ghana's recent score on the Global Corruption Barometer was 4.7, similar to that of Mexico (4.6) and Jamaica (4.5; Hardoon \& Heinrich, 2013). There are also widespread reports of human rights violations and procedural impropriety, including the police beating of suspects, arrests without warrants, and the detention of suspects beyond constitutionally permitted limits (Tankebe, 2010). Violence and insecurity are features of Ghanaian social life, especially in urban areas. There is evidence that, for a variety of reasons, most victims of crime do not report their victimization to the police. For example, one study found that $84.6 \%$ of robbery victims and $82.1 \%$ of assault victims did not report their victimization to the police (UNODC, 2010). Yet, reports indicate widespread fear of criminal victimization (Adu-Mireku, 2002). Attempts to address these fears have taken the form of vigilante violence and police use of extrajudicial killings of suspects (Tankebe, 2013b).

\section{Method}

\section{Data}

This study uses cross-sectional survey data derived from two university-based samples. Though data collection efforts took place on different continents, survey administration protocols 
were nearly identical across research settings. The in-class surveys were conducted between August 2010 and September 2011. Members of the research team were granted permission from 8 instructors at a large public university in the southwestern region of the US and one instructor at a large university in Ghana to survey their classes, resulting in 10 classes total (9 in the US and 1 in Ghana). In the US, 9 sections of a lower-level criminal justice course were surveyed. This course is required for criminology and criminal justice majors and also fulfills a general education requirement for all students at the university. In Ghana, one large lecture course was selected. These two courses provide a good cross-section of students enrolled at both universities. Prior to administering the surveys, potential participants were informed that their participation was voluntary, and that their responses were completely anonymous. On average, the survey took about 20 minutes to complete.

For the US sample, a total of 522 individuals were invited to participate in the study. Only 6 people declined the invitation, resulting in a $98.95 \%$ participation rate. For the Ghana sample, 459 people were invited to participate, and 15 individuals did not wish to be part of the study (96.7\% participation rate). Missing cell information was handled using similar response pattern imputation (SRPI, or hot decking). This procedure has been shown to consistently provide sensible values and to work well relative to other commonly-used modes of data imputation (Andridge \& Little, 2010; Gmel, 2000). Missing cell values were imputed using PRELIS 2.3 (Scientific Software International, Chicago, IL).

Because the sampling strategy drew survey data from nonrandom samples from specific segments of the populations in Ghana and the US, the results reported below do not generalize easily to broader populations, such as all college-age individuals in the two countries. However, research has shown that patterns of correlations between psychological variables differ only 
minimally between studies using random and convenience samples (Hultsch, MacDonald, Hunter, Maitland, \& Dixon, 2002). As will be demonstrated, many of the observed correlations in this study are consistent with decades of crime and justice research. Nevertheless, the validity and generalizability of the findings reported herein can only be determined via replication.

\section{Survey Instrument}

The survey was conducted in English, and in addition to soliciting information about personal attributes, the instrument also consisted of a variety of items used previously in police legitimacy research (see, e.g., Sunshine \& Tyler, 2003; Tankebe, 2013a; Tyler, 1990). Items were selected based on clarity and performance in prior empirical assessments. In terms of structure, both surveys (US and Ghana) began with an assessment of a key personality trait (i.e., self-control). Next, participants were queried about their compliance with various laws and willingness to participate in the criminal justice process. The core of the survey consisted of 42 items, each of which featured the same 4-point response set (strongly agree, agree, disagree, strongly disagree). The 16 items used to construct the police legitimacy scale were included in this section. Note that the remaining 26 survey items largely consisted of crime and justice-related items for scales that are beyond the scope of the present study and items that were originally intended for use in the study but were excluded during the preliminary analysis because they did not load clearly on any factor. The 42 items in this section were randomized prior to survey construction, which is a commonly used strategy to minimize order-effect bias (Perreault, 1975). The final section of the survey asked respondents for personal information (e.g., age and gender). 


\section{Dependent Variables}

Two dependent variables are used in this study. The first measure, cooperation with the police, is a 5-item scale that has been used previously in legitimacy research and shown to perform well (see Reisig, Tankebe, \& Meško, 2012). In both research settings, participants were asked to self-report the likelihood that they would cooperate in a variety of circumstances. The items reflect different types of crimes and different ways of cooperating with legal authorities, such as reporting various crimes the respondent had witnessed (e.g., "steal another person's wallet," "bribe a government official," and "break into a house or car"), being interviewed by police (e.g., "volunteer information if you witnessed the theft"), and participating in court proceedings (e.g., "volunteer to serve as a witness in a criminal court case involving a crime that you witnessed"). Each item featured a closed-ended response set ranging from 1 (very unlikely) to 4 (very likely). The levels of internal consistency exceeded conventional thresholds (Cronbach's $\alpha=.77$ for US \& .80 for Ghana). The scales are coded so that higher scores reflect greater willingness to cooperate with the police.

The second outcome measure, compliance with the law, is a multi-item scale. Participants were asked how frequently they had engaged in different illegal acts in both the US (e.g., "Broke traffic laws," "Used marijuana or some other drug," and "Bought something you thought might be stolen") and Ghana (e.g., "Offered a bribe to a public official," "Destroyed property belonging to another person on purpose," and "Illegally downloaded music or movies from the Internet") during the 6 months leading up to the survey. Note that the survey items used in the US do not perfectly correspond with those administered in Ghana. Some of the minor offenses included in the US scale, "illegally disposed of trash or litter" and "made a lot of noise at night," are not against the law in Ghana. What is more, traffic offenses among students in Ghana are infrequent 
because so few of them have access to an automobile. Such differences should not be cause for concern. After all, legitimacy is posited to be related to all forms of compliance, and the nature of compliance scales often vary not only between studies but within studies too (e.g., assessing the effect of legitimacy on the different types or classifications of crime; see Papachristos, Meares, \& Fagan, 2012; Reisig et al., 2014; Tyler \& Jackson, 2014). A closed-ended response set was used, ranging from frequently (coded 1) to never (coded 4). Levels of internal consistency were acceptable (Cronbach's $\alpha=.69$ for US \& .61 for Ghana). The scales were coded so that higher scores indicate greater compliance.

To assess the underlying structure of the two outcome variables, the 11 survey items were entered into an exploratory principal-axis factor model (with promax rotation) for each sample. Using the K1 rule (i.e., eigenvalues, or $\lambda$, greater than 1), a two-factor solution emerged for the US sample ( $\lambda=2.43$ for cooperation and 1.91 for compliance) and the Ghana sample $(\lambda=2.01$ for cooperation and 1.29 for compliance). Structure and pattern loadings for all four latent variables were $\geq .30$. Both outcome measures are operationalized as weighted factor scores. The Pearson's $r$ coefficients for the two scales are .23 (US sample) and .05 (Ghana sample), indicating that the scales reflect distinct latent constructs.

\section{Independent Variables}

Police legitimacy. This study conceives police legitimacy as multidimensional in nature. The first dimension, lawfulness, reflects whether police officers are seen as working within established rules (e.g., "When the police deal with people, they always behave according to the law") and is operationalized as a 3-item scale (Cronbach's $\alpha=.76$ for US \& .57 for Ghana). Procedural fairness is the second dimension, capturing the extent to which the police authority is exercised in a way that is fair, respectful, and evenhanded. This scale includes 7 survey items 
that reflect the two components of procedural fairness: quality of interpersonal treatment (e.g., "The police treat citizens with respect") and quality of decision making (e.g., "The police make decisions based on the facts"; Cronbach's $\alpha=.87$ for US \& .80 for Ghana). The third dimension, distributive fairness, captures variation in police fairness in outcomes and allocations of resources (e.g., "The police make sure citizens receive the outcomes they deserve under the law”). This scale consists of 3 survey items (Cronbach's $\alpha=.73$ for US \& .69 for Ghana). Finally, police effectiveness is the hypothesized fourth dimension, reflecting the ability of police to successfully respond to citizens' safety and security needs (e.g., "There are not many instances of crime in my neighborhood"; see Tankebe, 2009a). This scale is also comprised of 3 survey items (Cronbach's $\alpha=.62$ for US \& .69 for Ghana). All 4 scales were coded so that higher scores reflect more favorable personal judgments about the police. A complete list of survey items used to construct the police legitimacy scale is provided in Table 1.

\section{[Insert Table 1 about here]}

The 16 survey items that are hypothesized to reflect the 4 dimensions of police legitimacy were entered into a second-order confirmatory factor-analytic model. The first-order consists of measurement models for each of the postulated dimensions. Given that the survey items feature ordinal response sets, the use of Mplus to estimate the second-order confirmatory factor-analytic model was appropriate because of its capability to accommodate nonnormality without reliance on large samples (Muthén, du Toit, \& Spisic, 1997). In addition, a robust weighted least-squares estimator using a diagonal weight matrix (WLSMV) is the default estimator for analyses involving categorical endogenous variables in Mplus (Muthén \& Muthén, 2012). Model fit was evaluated using the chi-square goodness-of-fit test statistic provided by WLSMV estimation, the 
comparative fit index (CFI), Tucker-Lewis index (TLI), and the root mean square error of approximation (RMSEA).

Many of the indices indicated good fit: CFI $=.97$ for US \& .960 for Ghana, TLI $=.97$ for US \& .95 for Ghana, RMSEA = .07 for US \& .08 for Ghana. Traditional thresholds for fit statistics vary and are contested in the literature. CFI and TLI values of .95 or greater are frequently used to demonstrate reasonably good fit. While RMSEA values of .06 or lower are sometimes cited as the preferred cutoff, MacCallum, Brown, and Sugawara (1996) found that values ranging from 0.08 to 0.10 reflect mediocre fit. The chi-square goodness-of-fit test failed to suggest a good model fit $\left(\chi^{2}=347.64\right.$ for US \& 380.90 for Ghana, $p<.01$ for both), which was expected since both sample sizes exceed 400 cases. Under such conditions, the chi-square test almost always achieves statistical significance (Kenny, 2014). In the end, model fit indices are influenced by a number of factors (e.g., estimation method, distributional characteristics, and nature of the data), and fit assessments are typically most reliable when multiple indices are taken into consideration (Brown, 2006). Finally, the constituent indicators for each latent variable at both levels all load significantly (all loadings are significant at a level of $p<.01$ ). Specifically, as Figure 2 shows, the magnitude of the standardized loadings at the first order is sufficient $(>.55)$. At the second order, each of the 4 dimensions loads strongly onto police legitimacy. The model fit statistics for both samples are acceptable, indicating that police legitimacy can be operationalized as factor scores from the second-order confirmatory factor-analytic models. Put simply, the 4-dimensional police legitimacy model is reasonably consistent with the data in both samples. Scales are coded so that higher scores reflect higher levels of police legitimacy.

[Insert Figure 2 about here] 
Obligation to obey. The obligation to obey scale is comprised of 3 survey items: "You should accept police decisions because that is the proper or right thing to do," "People like me have no choice but to obey the directives of the police," and "You should do what the police tell you to do even if you disagree." Each item featured a 4-point response set ranging from strongly disagree (coded 1) to strongly agree (coded 4). The level of internal consistency for the two scales did not meet conventional cutoffs (Cronbach's $\alpha=.58$ for US \& .54 for Ghana). Low reliability estimates for obligation scales are relatively common (see Reisig et al., 2007; Tyler, 1990; Tyler \& Huo, 2002). However, the confirmatory factor-analytic models for categorical response items showed that the model fit the data reasonably well in both samples (RMSEA $=$ .07 for US \& .08 for Ghana; CFI $=.99$ for US \& .98 for Ghana; TLI $=.982$ for US \& .97 for Ghana) and the standardized loadings are acceptable ( $\geq .50$ for US $\& \geq .40$ for Ghana). Obligation to obey is operationalized using saved factor scores and coded so that higher scores reflect a greater sense of obligation to obey police directives.

Demographic variables. Prior research shows that levels of cooperation vary with individual characteristics. For example, research shows that males and racial/ethnic minorities are less likely to cooperate with the police relative to females and whites (Reisig et al., 2007). When it comes to compliance, it is well documented that males break the law more frequently than females (see Heidensohn \& Silvestri, 2012), and that involvement in crime varies with age (Ulmer \& Steffensmeier, 2014). Accordingly, two demographic variables are included in the assessments conducted with both the US and Ghana samples. First, male is a dichotomous measure where male participants are coded as 1 (females $=0$ ). Second, age is an orderedcategorical variable ranging from 18 years (coded 1) to 25 years and older (coded 8). Since heterogeneity in racial and ethnic backgrounds is restricted to the US sample, a third 
demographic variable — white $(1=$ yes, $0=$ racial/ethnic minority $)$ - is included in the multivariate models estimated using US data.

Low self-control. Self-control, broadly conceptualized to reflect the ability to control one's emotions and behavior, has been characterized as one of the strongest and most consistent known correlates of law breaking behavior (Pratt \& Cullen, 2000). It is becoming customary to include low self-control scales in models assessing the impact of police legitimacy on compliance with the law (see, e.g., Reisig, Wolfe, \& Holtfreter, 2011). The current study uses Tangeny, Baumeister, and Boone's (2004) 13-item Brief Self-Control scale, but its use is restricted to the compliance with the law models because theory and research on why and how self-control potentially influences voluntary participation in the criminal justice process (e.g., calling the police to report a crime) is underdeveloped. The scale includes items that reflect the different dimensions of self-control: impulse control ("I say inappropriate things"), healthy habits ("I refuse things that are bad for me"), self-discipline ("I wish that I had more self-discipline"), and work ethic ("Pleasure and fun sometimes keep me from getting work done"). Participants were asked how well each survey item described them on a closed-ended response scale ranging from "not at all" to "very much." Low self-control is an additive scale where higher scores reflect lower levels of self-control. The level of internal consistency is acceptable for both samples (Cronbach's $\alpha=.83$ for US \& .67 for Ghana). Summary statistics for the variables used in the study are provided in Table 2.

[Insert Table 2 about here]

\section{Data-Analytic Strategy}

A series of ordinary least-squares (or linear) regression equations are estimated to evaluate the directional accuracy of the Bottoms-Tankebe police legitimacy scale in a multivariate context. 
To gauge whether obligation to obey mediates the main effect of legitimacy, two equations for each outcome measure are estimated. The first equation included police legitimacy and the control variables. In the second equation, the obligation to obey scale featured in the specification. This modeling strategy was followed by Tankebe (2013a). The multivariate regression equations presented in the current study were estimated using Stata 13 (StataCorp LP, College Station, TX). A series of model diagnostics were performed to ensure that the estimates were unbiased. None of the bivariate correlation coefficients for the independent variables exceed an absolute value of .80. The variance inflations factors (VIF) for the regression models presented below are less than 3 . These estimates indicate that levels of collinearity present in the linear regression models is not threatening. Finally, robust standard errors are used because Breusch-Pagan tests revealed evidence of heteroscedastic errors.

\section{Results}

To test some of the hypotheses of interest (e.g., obligation to obey partially mediates the relationship between legitimacy and compliance), three empirical conditions must be established (see MacKinnon, Krull, \& Lockwood, 2000). First, it is necessary to confirm that obligation to obey is significantly related to the outcomes measures. The Pearson's correlation coefficients for the US sample are encouraging: the zero-order relationship between the obligation scale and compliance with the law is positive $(r=.36)$ and significant at the .01 level. A similar association is observed between obligation to obey and cooperation with the police $(r=.31, p<.01)$. A similar pattern emerges when considering the Ghana sample-obligation scores are significantly and positively correlated with both cooperation $(r=.14, p<.01)$ and compliance $(r=.11, p<$ .05). In terms of magnitude, results from z-test of correlations show that obligation to obey is less strongly connected to the outcome variables in the Ghana sample $(\mathrm{z}=-2.77, p<.01$ for 
cooperation and -4.10 at $p<.001$ compliance). Turning to the second requirement, the bivariate relationships between the obligation scale and police legitimacy are quite strong $(r=.79$ for US \& .68 for Ghana). As already noted, these relatively strong correlations did not introduce harmful levels of collinearity into the regression analyses presented below. Finally, police legitimacy correlates with both cooperation $(r=.28, p<.01)$ and compliance $(r=.34, p<.01)$ in the US sample. Positive and statistically significant associations with police legitimacy are also observed using the Ghana sample ( $r=.17$ for cooperation $\& .11$ for compliance). These estimates satisfy the requirements for observing mediating relationships. Attention now shifts to the multivariate assessment.

In Table 3, the cooperation with police scale is regressed onto two different sets of independent variables from both the US and Ghana samples. The $F$ tests are statistically significant at the .01 level, indicating that the linear regression equations are significantly better in terms of explanatory power than what would be expected by chance alone. In Model 1 , the $t$ ratio for the police legitimacy estimate is statistically significant. More formally, the unstandardized partial regression coefficient $(b)$ indicates that a one unit increase in police legitimacy corresponds to a .40 unit increase in cooperation with police for the US sample, holding all other variables constant. A similar parameter estimate is observed in the Ghana sample $(b=.41)$. These two models show that the previously reported bivariate associations persist when more rigorous statistical techniques are used. In Models 2 and 4, the obligation to obey scale is included. The data reveal several specific findings that warrant attention. First, in both equations, the inclusion of the obligation scale attenuates the police legitimacy estimate. More specifically, the legitimacy estimate in the US sample is reduced by $65 \%$ and the $t$-ratio is no longer statistically significant. As expected, the test statistic for obligation to obey achieves 
statistical significance, thus suggesting that the effect of police legitimacy on cooperation is indirect. A consistent, though slightly different, story emerges for the Ghana sample in that the inclusion of the obligation to obey scale partially mediates the relationship between legitimacy and cooperation with the police (from .41 in Model 3 to .30 in Model 4), a reduction of approximately $22 \%$. Unlike the model using the US data, the $t$-ratio for police legitimacy is statistically significant in the full model. This finding closely mirrors that of Tankebe (2013a). To sum up, the results from the regression models in Table 3 largely replicate Tankebe's prior findings from his study of London residents. The question remains, however, whether a similar pattern of findings will be observed when considering compliance with the law.

[Insert Table 3 about here]

Compliance with the law is regressed onto police legitimacy, obligation to obey, and the control variables in Table 4. The models using the US data show that, as hypothesized, police legitimacy is significantly associated with compliance, even after controlling for one of the strongest known predictors of criminal activity (i.e., low self-control). This finding is consistent with prior research showing that the legitimacy-compliance relationship is not confounded by individual variations in self-control (see Reisig et al., 2011). The story changes slightly in Model 2 when the obligation scale enters the model: the estimate for police legitimacy is reduced by $36 \%$, though the corresponding $t$-ratio remains statistically significant. Obligation to obey is also a significant correlate in Model 2. Again, although a different outcome measure is being used, this pattern of findings is also consistent with the results reported by Tankebe (2013a). Using the Ghana data, Model 3 shows that police legitimacy is associated with compliance with the law. The inclusion of obligation to obey in Model 4 only results in an approximately $20 \%$ reduction in the legitimacy coefficient, yet this attenuation is sufficient to reduce the size of the $t$-ratio below 
commonly used thresholds for determining statistical significance. Similarly, the obligation to obey test statistic does not reach statistical significance in Model 4. Interestingly, however, obligation to obey does appear to be linked to variations in compliance in a reduced regression equation that does not include police legitimacy in the model specification. Note that none of the VIF estimates in this model exceed $1.6($ mean VIF $=1.26)$, largely ruling out collinearity as an explanation for the attenuation.

\section{[Insert Table 4 about here]}

\section{Discussion}

Until now, Tankebe's (2013a) London study was the only test of Bottoms and Tankebe's (2012) theoretical argument. Like Tankebe, this study also constructed a multidimensional police legitimacy scale. The findings from the second-order confirmatory factor models are consistent with Bottoms and Tankebe's expectations. In studies conducted in contexts as different as Ghana, the United States, and the United Kingdom, the rightness of police power is grounded in judgments of police effectiveness, lawfulness, procedural fairness, and distributive fairness.

Admittedly, the results from the factor analysis are not terribly surprising. In many ways, the findings merely reflect the popular understanding of legitimacy. The following illustrates this point briefly. In June 2013, The Washington Post and The Guardian published evidence of an electronic surveillance program by the National Security Agency (NSA) known as PRISM. The ensuing debate focused on the legitimacy of such an intelligence gathering and sharing program. Both critics and supporters of the NSA framed their analysis of the legitimacy of the Agency's actions with reference to the four dimensions of legitimacy examined in this study: lawfulness (“Has the NSA violated the law?"), distributive and procedural justice ("Does PRISM violate citizens' privacy?" and "Does the program target American Muslims?"), and effectiveness ("Is 
PRISM an effective counter-terrorism tool?"; see Klayman et al. v. Obama et al., 2013; ACLU et al. v. Clapper et al., 2013). Similar questions were also raised in the recent debate about the Central Intelligence Agency's (CIA) use of enhanced interrogation techniques (e.g., "Are these techniques effective?," "Are they in accordance with American values?," and "Are they lawful?"). These are not questions about trust, obligation, or even about support for the NSA and the CIA. On the contrary, these are questions about the rightness of actions of these agencies. Questions about whether people support the NSA and the CIA, feel obliged to obey their directives, or even seek to limit or extend the powers of these agencies are questions that are consequent to the perceived legitimacy of their actions.

The second objective of the study was to assess the relationship that police legitimacy and feelings of obligation to obey the police have with cooperation with the police and compliance with the law. The results clearly show that police legitimacy is associated with individual willingness to cooperate with the police both in the US and in Ghana. However, an interesting finding emerged regarding the role of obligation in both settings: in the US, feelings of obligation to obey the police fully mediated the relationship between legitimacy and cooperation; in Ghana, legitimacy exhibited effects on cooperation that were independent of the obligation scale. Perhaps the most striking was how little both legitimacy and obligation mattered for cooperation in Ghana: they accounted for less than $6 \%$ of the variance in cooperation.

Overall, however, the evidence that legitimacy influences cooperation in both Ghana and the US reinforces the arguments that the degree of cooperation with legal authorities can secure from citizens sometimes depends on the normative status of those authorities (Beetham, 1991). Apart from Tankebe (2013a), no prior studies have combined lawfulness, procedural fairness, distributive fairness, and police effectiveness to construct an omnibus police legitimacy scale. 
Nevertheless, the results can be read as broadly consistent with prior studies that have examined the influence of some of these individual elements of the Bottoms-Tankebe legitimacy model (see, e.g., Bradford, 2014; Hough, Jackson, \& Bradford, 2013; Murphy \& Cherney, 2012a; Tankebe, 2009a). The influence of obligation on cooperation is also supportive of prior findings (see, e.g., Tyler \& Fagan, 2008; Tyler, Schulhofer, \& Huq, 2010; Tankebe, 2013a), but contradicts evidence reported by other researchers (see, e.g., Tankebe, 2009a; Reisig et al., 2007).

Both in the US and in Ghana, police legitimacy was linked to compliance with the law, independent of individual variations in low self-control. There is a large body of evidence to show that high self-control is a robust predictor of compliance with the law (Pratt \& Cullen, 2000). Yet the evidence forwarded in the present study shows that, together with police legitimacy, self-control explains between a third (in the US sample) and a tenth (in Ghana sample) of the variation associated with compliance. Thus, there is a considerable amount of compliant behavior that cannot be explained by references to police legitimacy and self-control. In the US, the sense of obligation to obey the police was associated with compliance. This evidence from the US is consistent with much of what is known from prior studies (see, e.g., Sunshine \& Tyler, 2003; Tyler, 1990; Jackson et al., 2012). Unlike the US, the data from Ghana show that, controlling for perceived obligation to obey the police washed out the influence of legitimacy on compliance. Yet obligation itself does not appear to influence compliance with the law.

How are we to account for the apparent irrelevance or weak explanatory power of legitimacy on compliance and cooperation in Ghana? First, legitimacy is only one possible motive for cooperative and complaint behavior; other motives include prudential or self-interested 
calculations, habit, and even fear (Bottoms, 2002; Reisig \& Lloyd, 2009; Tankebe, 2013a). It might be that these motives hold a greater sway in the Ghanaian context. Thus, future studies that examine their influence might contribute to a fuller explanation of people's support for the police and law-abiding behavior. The Second explanation may be gleaned from Ekeh's (1975) analysis of politics in postcolonial Africa. Ekeh identifies two coexisting publics in Africa: the "primordial public" and the "civic public". The former comprises traditional political arrangements based on moral imperatives and sentiments of the extended family and ethnic or tribal group. Here, individuals view their duties as moral obligations to benefit and to sustain a primordial public of which they see themselves as members. The civic public, on the other hand, is the political space inhabited by the post-colonial state and its criminal justice institutions. Ekeh argues that people have weak moral identification and commitment to this public. The reason for this condition is partly a failure by ordinary Africans to decouple, cognitively, colonial and postcolonial structures, and hence a transfer of legitimacy deficits from colonialism into the violation of the violation of the constitutional rights of citizens (Tankebe 2009b, 2013b). These conditions would seem to produce feelings of obligation to institutions that are not sufficiently compelling as to trigger support for such institutions or obedience to the laws of the civic public (Tankebe, 2009a). It is also possible for the police in countries such as Ghana to score highly on the Bottoms-Tankebe four-dimensional view of legitimacy but for such perceptions to have no decisive influence on cooperation with police or compliance with laws (see Tankebe, 2009a, p. 1282).

\section{Implications for Research, Policy, and Practice}

Prior studies suggest that police managers have much to gain from a legitimacy-based law enforcement strategy. However, the results reported in the present study suggest it is important to 
be cautious and to avoid an exaggerated expectation of the contribution legitimacy can make to the reproduction of social order. For researchers, two implications flow from the results. First, is to move beyond Bottoms-Tankebe conceptions and to explore whether there is an understanding or construction of police legitimacy that is peculiar to social, political, and legal contexts like that of Ghana. Second to move beyond legitimacy in order to establish whether or not there are mechanisms of compliance and cooperation belonging exclusively to specific communities, and how well legitimacy stands up against those mechanisms. Such context-specific investigations will help to address what Mouzelis (2008, p. 19) calls "contextless generalizations"; that is to say, to draw conclusions that are trivial or even wrong. Reisig et al. (2014) caution that most conclusions drawn about the legitimacy-behavior link portray the underlying model as a general theory, capable of explaining cooperation with police and compliance with all laws across time and space. The findings reported in this study suggest that the contribution legitimacy makes to cooperative and law-abiding behavior might differ across societies. Beetham (1991) defined the concept of "legitimacy-in-context" to mean that understandings of the rightness of power differ across time and space; perhaps this definition should be extended also to include the predictive power of legitimacy. Future work should focus on understanding the specific contexts in which legitimacy can make a contribution to social order, and the nature of that contribution.

\section{Limitations}

The current study is not without limitations. First, we relied cross-sectional data from samples of university studies. As previously noted, this makes it difficult to establish how far the findings can be generalized to the respective societies from which the samples were drawn. While the students may share values of the broader society, there is a need to establish this empirically 
using data from household surveys. Even such data will not overcome the challenges of drawing causal inferences from a cross-sectional study. Future studies that adopt a longitudinal design will contribute to correcting this limitation in our study. Such studies may help address the following questions: How do people develop views about police legitimacy? Why and how do such views change over time? Are there turning points in the development of legitimacy attitudes, and to what extent are any such turning points shaped both by experiences of policing and structural forces beyond policing? What is the degree of stability and change in legitimacybehavior link over a person's life-course?

Second, we did not disaggregate our outcomes into specific types of cooperative and compliance behaviors. It is very much an open question as to whether the influence of BottomsTankebe model of legitimacy varies across specific types of behaviors. There is a related limitation: unlike compliance, our measures of cooperative behavior captured people's intentions rather than actual behavior. Given the well-established evidence on gap between attitudes and behavior, studies focusing on actual cooperative behavior will improve our understanding of legitimacy-behavior link.

Third, our study offers only a partial test of the Bottoms-Tankebe model, which claims that legitimacy is better understood by investigating its meaning within specific socio-cultural contexts. It is argued that such an investigation would reveal lawfulness, procedural justice, distributive justice and effectiveness as the basic dimensions of legitimacy. A fuller test of this hypothesis will require a mixed method research design, which Tankebe (2014, p. 254) argues may be a two-staged process. The first involves use of focus group discussions and intensive interviews to establish the subjective meanings of legitimacy within local communities. What 
expectations do people have of the police? What to them to make police power morally valid? What sort of issues comes to their minds when think about whether or not police have to right to exercise power? As prisons researchers have shown, this qualitative can be illuminating in their own right (e.g. Liebling, with Arnold, 2004). However, for quantitative researchers, this could form the basis for a second stage: extract and develop survey items to be validated using a larger sample.

\section{References}

ACLU et al. v. Clapper et al., WL 6819708 (S.D.N.Y. December 27, 2013).

Adu-Mireku, S. (2002). Fear of crime among residents of three com- munities in Accra, Ghana. International Journal of Comparative Sociology, 43, 153-168.

doi: $10.1177 / 002071520204300203$

Afrobarometer Report. (2014). Trust and corruption in public institutions: Ghanaian opinions. Retrieved from the Ghana Center for Democratic Development website: http://www.cddgh.org/_upload/general/GHA_AB_R6_Dissemination3\%20(Trust\%20\%20Cor ruption)_01dec_2014_FINAL.pdf

Andridge, R., \& Little, R. (2010). A review of hot deck imputation for survey non-response. International Statistical Review, 78, 40-64. doi: 10.1111/j.1751-5823.2010.00103.x

Beetham, D. (1991). The legitimation of power. London: Macmillan.

Beetham, D. (2013). Revisiting legitimacy, twenty years on. In J. Tankebe \& A. Liebling (Eds.), Legitimacy and criminal justice: An international exploration (pp. 19-36). Oxford: Oxford University Press. 
Belur, J. (2010). Permission to shoot? Police use of deadly force in democracies. New York: Springer.

Bottoms, A. (2002). Morality, crime, compliance and public policy. In A. Bottoms \& M. Tonry (Eds.), Ideology, crime and criminal justice: A symposium in honour of Sir Leon Radzinowicz. (pp. 20-51). Cullompton, UK: Willan.

Bottoms, A., \& Tankebe, J. (2012). Beyond procedural justice: A dialogic approach to legitimacy in criminal justice. Journal of Criminal Law \& Criminology, 102, 119-170.

Bradford, B. (2014). Policing and social identity: Procedural justice, inclusion, and cooperation between police and public. Policing \& Society, 24, 22-43.

doi: 10.1080/10439463.2012.724068

Brown, T. (2006). Confirmatory factor analysis for applied research. New York and London: The Guilford Press.

Coicaud, J-M. (2002). Legitimacy and politics: A contribution to the study of political right and political responsibility. Cambridge, UK: Cambridge University Press

Durose, M., \& Langton, L. (2013). Requests for police assistance, 2011. Washington, DC: U.S. Government Printing Office.

Eisner, M., \& Nivette, A. (2013). Does legitimacy cause crime? A review of the evidence. In J. Tankebe \& A. Liebling (Eds.), Legitimacy and criminal justice: An international exploration (pp. 308-325). Oxford: Oxford University Press.

Ekeh, P. (1975). Colonialism and the two publics in Africa: A theoretical statement. Comparative Studies in Society \& History, 17, 91-112. doi: 10.1017/S0010417500007659

Fagan, J., \& Tyler, T. R. (2005). Legal socialization of children and adolescents. Social Justice Research, 18, 217-242. doi: 10.1007/s11211-006-0621-4 
Gau, J. (2011). The convergent and discriminant validity of procedural justice and police legitimacy: An empirical test of core theoretical propositions. Journal of Criminal Justice, 39, 489-498. doi: 10.1016/j.jcrimjus.2011.09.004

Gmel, G. (2001). Imputation of missing values in the case of multiple item instrument measuring alcohol consumption. Statistics in Medicine, 20, 2369-2381. doi: 10.1002/sim.837

Gyimah-Boadi, E., \& Brobbey, V. (2013). Countries at the Crossroads 2012: Ghana. Retrieved from Freedom House website: https://freedomhouse.org/sites/default/files/Ghana\%20\%20FINAL.pdf

Hardoon, D., \& Heinrich, F. (2013). Global corruption barometer 2013. Berlin, Germany: Transparency International.

Heidensohn F., \& Silvestri, M. (2012). Gender and crime. In M. Maguire, R. Morgan, \& R. Reiner (Eds.), The Oxford handbook of criminology (pp. 336-369). Oxford and New York: Oxford University Press.

Hertogh, M. (2015). What moves Joe Driver? How perceptions of legitimacy shape regulatory compliance among Dutch Traffic Offenders. International Journal of Law, Crime \& Justice, 43, 214-234. doi: 10.1016/j.ijlcj.2017.09.001

Hough, M., Jackson, J., \& Bradford, B. (2013). Legitimacy, trust, and compliance: An empirical test of procedural justice theory using the European Social Survey. In J. Tankebe \& A. Liebling (Eds.), Legitimacy and criminal justice: An international exploration (pp. 326-352). Oxford: Oxford University Press.

Hultsch, D., MacDonald, S., Hunter, M., Maitland, S., \& Dixon, R. (2002). Sampling and generalizability in developmental research: Comparison of random and convenience samples of older adults. International Journal of Behavioral Development, 26, 345-359. 
doi: $10.1080 / 01650250143000247$

Jackson, J., Bradford, B., Hough, M., Myhill, A., Quinton, P., \& Tyler, T. R. (2012). Why do people comply with the law? Legitimacy and the influence of legal institutions. British Journal of Criminology, 52, 1051-1071. doi: 10.1093/bjc/azs032

Jackson, J., Bradford, B., Stanko, E., \& Hohl, K. (2012). Just authority? Trust in the police in England and Wales. Oxford: Routledge.

Jackson, J., Huq, A., Bradford, B., \& Tyler, T. R. (2013). Monopolizing force? Police legitimacy and public attitudes toward the acceptability of violence. Psychology, Public Policy, \& Law, 19, 479-497. doi: 10.1037/a0033852

Jauregui, B. (2013). Beatings, beacons, and big men: Police disempowerment and delegitimation in India. Law \& Social Inquiry, 38, 643-669. doi: 10.1111/1si.12030

Kenny, D. (2014). Measuring model fit. Retrieved from http://davidakenny.net/cm/fit.htm Klayman et al. v. Obama et al., 957 F. Supp. 2d 1 (D.D.C. 2013).

Lerner, M., \& Clayton, S. (2011). Justice and self-interest. Cambridge, UK: Cambridge University Press.

Liebling A. (with H. Arnold) (2004). Prisons and their Moral Performance: A Study of Values, Quality, and Prison Life. Oxford, U.K: Clarendon Press.

MacCallum, R., Browne, M., \& Sugawara, H. (1996). Power analysis and determination of sample size for covariance structure modeling. Psychological Methods, 1, 130-149. doi: 10.1037/1082-989X.1.2.130

MacKinnon, D., Krull, J., \& Lockwood, C. (2000). Equivalence of mediation, confounding, and suppression effect. Prevention Science, 1, 173-181. doi: 10.1023/A:1026595011371

Mouzelis, N. (2008). Modern and postmodern social theory. Cambridge, UK: Cambridge 


\section{University Press.}

Murphy, K., \& Cherney, A. (2012a). Fostering cooperation with the police: How do ethnic minorities in Australia respond to procedural justice-based policing? Australian \& New Zealand Journal of Criminology, 44, 235-257. doi: 10.1177/0004865811405260

Murphy, K., \& Cherney, A. (2012b). Understanding cooperation with police in a diverse society. British Journal of Criminology, 52, 181-201. doi: 10.1093/bjc/azr065

Muthén, B., du Toit, S., \& Spisic, D. (1997). Robust inference using weighted least squares and quadratic estimating equations in latent variable modeling with categorical and continuous outcomes. Unpublished manuscript.

Muthén, L., \& Muthén, B. (2012). Mplus user's guide (7 ${ }^{\text {th }}$ ed.). Los Angeles, CA: Muthén \& Muthén.

Papachristos, A., Meares, T., \& Fagan, J. (2012). Why do criminals obey the law? The influence of legitimacy and social networks on active gun offenders. Journal of Criminal Law \& Criminology, 102, 397-440.

Perreault, W. (1975). Controlling order-effect bias. Public Opinion Quarterly, 39, 544-551.

Pratt, T., \& Cullen, F. (2000). The empirical status of Gottfredson and Hirschi's general theory of crime: A meta-analysis. Criminology, 38, 931-964.

doi: 10.1111/j.1745-9125.2000.tb00911.x

Punch, M. (1985). Conduct unbecoming: The social construction of police deviance and control. London: Tavistock.

Reisig, M. D. (2010). Community and problem-oriented policing. Crime \& Justice: A Review of Research, 39, 1-53.

Reisig, M. D., Bratton, J., \& Gertz, M. (2007). The construct validity and refinement of process- 
based policing measures. Criminal Justice \& Behavior, 34, 1005-1028.

doi: $10.1177 / 0093854807301275$

Reisig, M. D., \& Lloyd, C. (2009). Procedural justice, police legitimacy, and helping the police fight crime: Results from a survey of Jamaican adolescents. Police Quarterly, 12, 42-62. doi: $10.1177 / 1098611108327311$

Reisig, M. D., Tankebe, J., \& Meško, G. (2012). Procedural justice, police legitimacy, and public cooperation with the police among young Slovene adults. Journal of Criminal Justice \& Security, 14, 147-164.

Reisig, M. D., Tankebe, J., \& Meško, G. (2014). Compliance with the law in Slovenia: The role of procedural justice and police legitimacy. European Journal of Criminal Policy \& Research, 20, 259-276. doi: 10.1007/s10610-013-9211-9

Reisig, M. D., Wolfe, S., \& Holtfreter, K. (2011). Legal cynicism, legitimacy, and criminal offending: The nonconfounding effect of low self-control. Criminal Justice \& Behavior, 38, 1265-1279. doi: 10.1177/0093854811424707

Reus-Smit, C. (2007). International crises of legitimacy. International Politics, 44, 157-174. doi:10.1057/palgrave.ip.8800182

Roemer, J. (1996). Theories of distributive justice. Cambridge, MA: Harvard University Press.

Sunshine, J., \& Tyler, T. R. (2003). The role of procedural justice and legitimacy in shaping public support for policing. Law \& Society Review, 37, 513-547.

doi:10.1111/1540-5893.3703002

Tangney, J., Baumeister, R., \& Boone, A. (2004). High self-control predicts good adjustment, less pathology, better grades, and interpersonal success. Journal of Personality, 72, 271-324. doi: 10.1111/j.0022-3506.2004.00263.x 
Tankebe, J. (2009a). Public cooperation with the police in Ghana: Does procedural fairness matter? Criminology, 47, 1265-1293. doi: 10.1111/j.1745-9125.2009.00175.x

Tankebe, J. (2009b). Self-help, policing and procedural justice: Vigilantism and the rule of law in Ghana. Law \& Society Review, 43, 245-269. doi: 10.1111/j.1540-5893.2009.00372.x

Tankebe, J. (2010). Public confidence in the police: Testing the effects of public experiences of police corruption in Ghana. British Journal of Criminology, 50, 296-319. doi: 10.1093/bjc/azq001

Tankebe, J. (2013a). Viewing things differently: The dimensions of public perceptions of police legitimacy. Criminology, 51, 103-135. doi: 10.1111/j.1745-9125.2012.00291.x

Tankebe, J. (2013b). In search of moral recognition? Policing and eudaemonic legitimation in Ghana. Law \& Social Inquiry, 38, 576-597. doi: 10.1111/1si.12025

Tankebe, J. (2014). Police legitimacy. In M. D. Reisig \& R. J. Kane (Eds.), The Oxford handbook of police and policing (pp. 238-259). New York and Oxford: Oxford University Press.

Tyler, T. R. (1990). Why people obey the law. New Haven, CT: Yale University Press.

Tyler, T. R., \& Fagan, J. (2008). Legitimacy and cooperation: Why do people help the police fight crime in their communities? Ohio State Journal of Criminal Law, 6, 231-275.

Tyler, T. R., \& Huo, Y. (2002). Trust in the law. New York: Russell Sage.

Tyler, T. R., \& Jackson, J. (2014). Popular legitimacy and the exercise of legal authority: Motivating compliance, cooperation, and engagement. Psychology, Public Policy, \& Law, 20, 78-95. doi: 10.1037/a0034514

Tyler, T. R., Schulhofer, S., \& Huq, A. (2010). Legitimacy and deterrence effects in counterterrorism policing: A study of Muslim Americans. Law \& Society Review, 44, 365- 
402. doi: 10.1111/j.1540-5893.2010.00405.x

Ulmer, J., \& Steffensmeier, D. (2014). The age and crime relationship: Social variation, social explanations. In K. Beaver, B. Boutwell \& J. C. Barnes (Eds.), The nurture versus biosocial debate in criminology (pp. 377-397). Newbury Park, CA: Sage. 


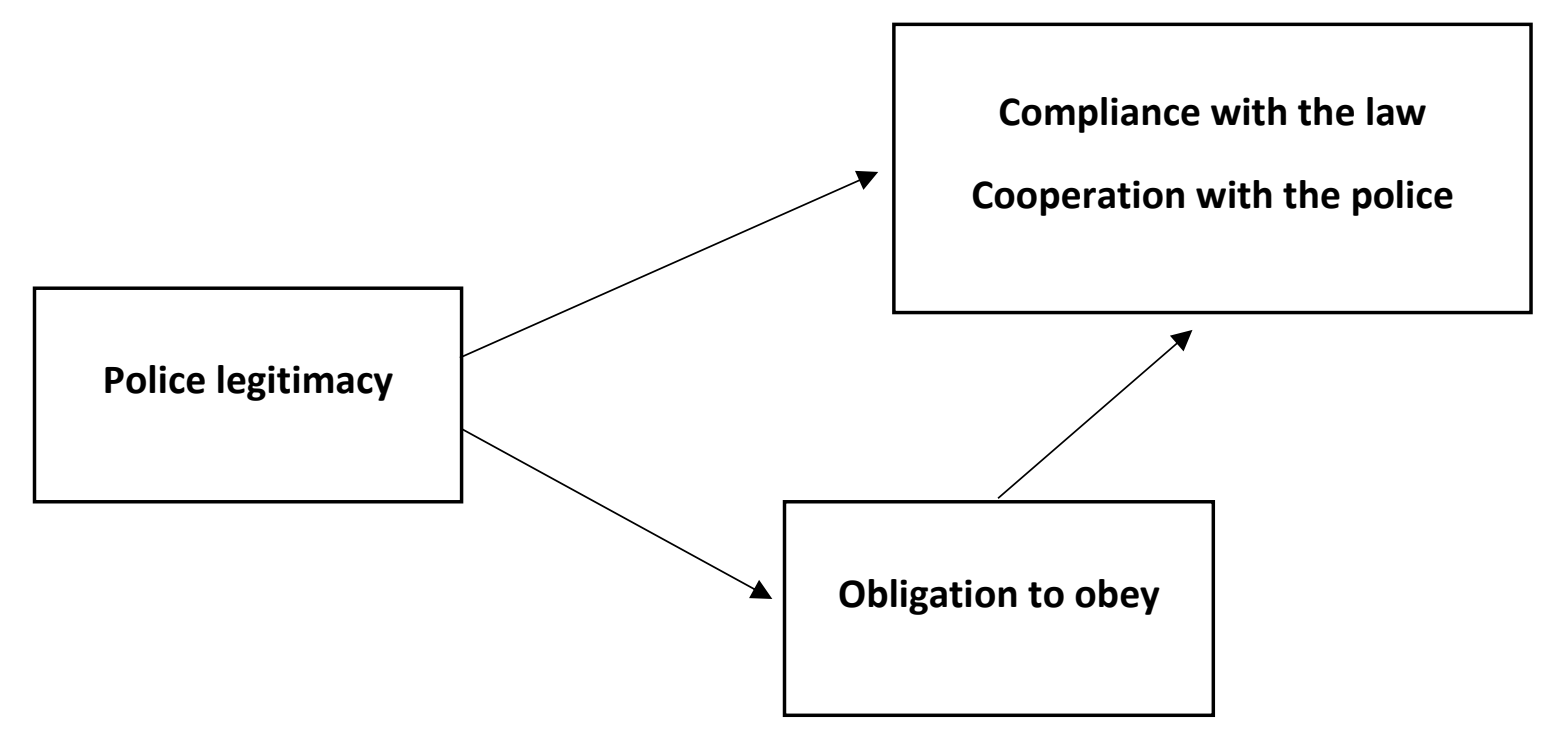

Figure 1. Research Hypotheses Tested 


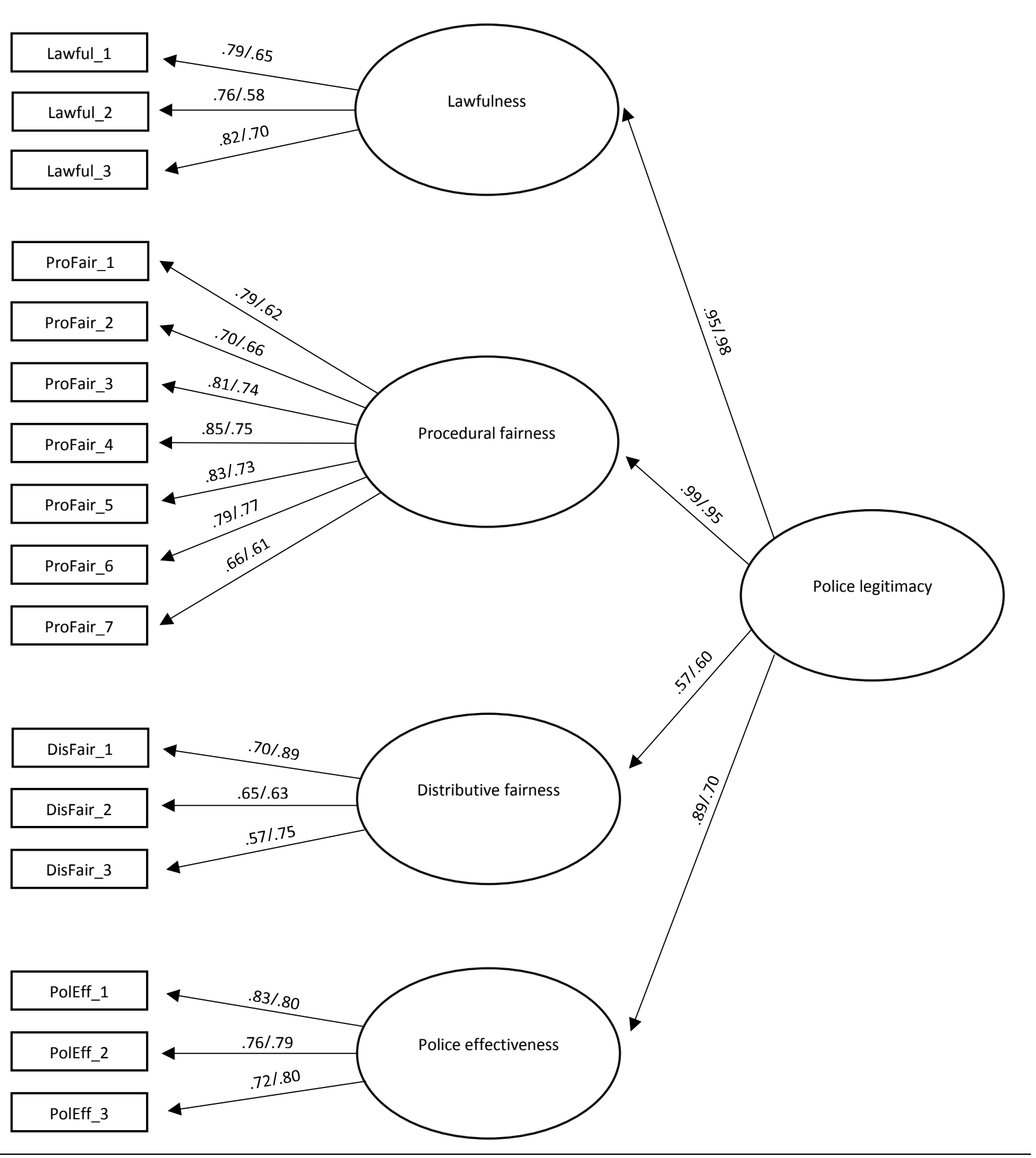

Figure 2. Two second-order confirmatory factor models of police legitimacy are featured. Entries are standardized estimates. For US sample: $\mathrm{CFI}=0.973, \mathrm{TLI}=0.968, \mathrm{RMSEA}=0.069$, and estimates presented to the left of the forward slash. For Ghana sample: $\mathrm{CFI}=0.960, \mathrm{TLI}=$ 0.952, RMSEA $=0.080$, and estimates presented to the right of the forward slash. 
Table 1

Summary Statistics for Legitimacy Scale Items by Dimension

Dimension and Item $\quad M \quad S D$

Lawfulness

1. When the police deal with people, they always behave according to the law

$2.50 / 2.14 \quad .70 / .72$

2. If I were to talk to police officers in my community, I would find their values to be very $\quad 2.71 / 2.39 \quad .74 / .77$ similar to my own

3. The police act in way that are consistent with my own moral values

Procedural Fairness

1. The police treat citizens with respect

$2.70 / 2.23 \quad .74 / .73$

2. The police take time to listen to people

$2.69 / 2.39 \quad .71 / .75$

3. The police treat people fairly

$2.62 / 2.12 \quad .70 / .69$

4. The police respect citizens' rights

$2.83 / 2.54 \quad .66 / .71$

5. The police are courteous to citizens they come into contact with

$2.90 / 2.44 \quad .62 / .67$

6. The police treat everyone with dignity

$2.48 / 2.16 \quad .71 / .71$

7. The police make decisions based on the facts

$2.79 / 2.51 \quad .71 / .79$

Distributive Fairness

1. The police provide the same quality of service to all citizens

2. The police enforce the law consistently when dealing with people

$2.72 / 2.46 \quad .63 / .72$

3. The police make sure citizens receive the outcomes they deserve under the law

$2.81 / 2.48 \quad .66 / .71$

Police Effectiveness

1. Crime levels in my neighborhood have changed for the better in the last year

$2.74 / 2.72 \quad .75 / .81$

2. There are not many instances of crime in my neighborhood

$2.75 / 2.69 \quad .88 / .83$

3. I feel safe walking in my neighborhood at night

$2.76 / 2.46 \quad .93 / .89$

Note. Item numbers in the far left-hand column correspond to the numbers and items presented in Figure 2. Summary statistics for the US sample are presented to the left of the forward slash. Summary statistics for the Ghana sample are featured to the right of the forward slash. 
Table 2

Summary Statistics for Study Variables

\begin{tabular}{|c|c|c|c|c|c|c|c|c|}
\hline \multirow[t]{2}{*}{ Variables } & \multicolumn{2}{|c|}{$M$ or $\%$} & \multicolumn{2}{|c|}{$S D$} & \multicolumn{2}{|c|}{ Minimum } & \multicolumn{2}{|c|}{ Maximum } \\
\hline & US & Ghana & US & Ghana & US & Ghana & US & Ghana \\
\hline Cooperation with the police & .00 & .00 & 1.00 & 1.00 & -3.56 & -3.06 & 1.23 & 1.69 \\
\hline Compliance with the law & .00 & .00 & 1.00 & 1.00 & -3.29 & -5.63 & 1.67 & 0.55 \\
\hline Obligation to obey & -.01 & .00 & .65 & .47 & -2.14 & -1.42 & 1.78 & 2.07 \\
\hline Police legitimacy & -.01 & .01 & .72 & .60 & -2.39 & -1.74 & 2.22 & 2.62 \\
\hline Low self-control & 33.90 & 30.90 & 8.78 & 7.37 & 13.00 & 14.00 & 61.00 & 55.00 \\
\hline Male & $49 \%$ & $46 \%$ & -- & -- & .00 & .00 & 1.00 & 1.00 \\
\hline Age & 2.56 & 3.58 & 2.05 & 2.02 & 1.00 & 1.00 & 8.00 & 8.00 \\
\hline White & $51 \%$ & --- & --- & --- & .00 & --- & 1.00 & --- \\
\hline
\end{tabular}


Table 3

Cooperation with Police OLS Regression Models

\begin{tabular}{|c|c|c|c|c|c|c|c|c|c|c|c|c|c|c|c|c|}
\hline \multirow[t]{4}{*}{ Variables } & \multicolumn{16}{|c|}{ Cooperation with police } \\
\hline & \multicolumn{8}{|c|}{ US Sample } & \multicolumn{8}{|c|}{ Ghana Sample } \\
\hline & \multicolumn{4}{|c|}{ Model 1} & \multicolumn{4}{|c|}{ Model 2} & \multicolumn{4}{|c|}{ Model 3} & \multicolumn{4}{|c|}{ Model 4} \\
\hline & $\begin{array}{c}b \\
(S E)\end{array}$ & $95 \%$ CI & $p$ & $t$ & $\begin{array}{c}b \\
(S E)\end{array}$ & $95 \% \mathrm{CI}$ & $p$ & $t$ & $\begin{array}{c}b \\
(S E)\end{array}$ & $95 \% \mathrm{CI}$ & $p$ & $t$ & $\begin{array}{c}b \\
(S E)\end{array}$ & $95 \% \mathrm{CI}$ & $p$ & $t$ \\
\hline Police legitimacy & $\begin{array}{r}.40 \\
(.07)\end{array}$ & $.26, .53$ & .00 & 5.75 & $\begin{array}{c}.14 \\
(.10)\end{array}$ & $-.04, .33$ & .13 & 1.50 & $\begin{array}{c}.41 \\
(.09)\end{array}$ & $.23,59$ & .00 & 4.42 & $\begin{array}{c}.30 \\
(.11)\end{array}$ & $.08, .52$ & .01 & 2.69 \\
\hline Obligation to obey & -- & -- & -- & -- & $\begin{array}{c}.35 \\
(.10)\end{array}$ & $.15, .56$ & .00 & 3.39 & -- & -- & --- & --- & $\begin{array}{c}.23 \\
(.13)\end{array}$ & $-.02, .48$ & .07 & 1.79 \\
\hline Male & $\begin{array}{l}-.17 \\
(.07)\end{array}$ & $-.35, .00$ & .06 & -1.92 & $\begin{array}{l}-.16 \\
(.09)\end{array}$ & $-.33, .01$ & .07 & -1.83 & $\begin{array}{c}.11 \\
(.10)\end{array}$ & $-.07, .30$ & .24 & 1.19 & $\begin{array}{l}.12 \\
(.10)\end{array}$ & $-.07, .30$ & .22 & 1.22 \\
\hline Age & $\begin{array}{c}.01 \\
(.02)\end{array}$ & $-.04, .06$ & .71 & .37 & $\begin{array}{c}.01 \\
(.02)\end{array}$ & $-.04, .06$ & .70 & .38 & $\begin{array}{l}-.00 \\
(.03)\end{array}$ & $-.05, .05$ & .92 & -.11 & $\begin{array}{l}-.00 \\
(.03)\end{array}$ & $-.05, .05$ & .97 & -.04 \\
\hline White & $\begin{array}{l}-.11 \\
(.09)\end{array}$ & $-.06, .29$ & .20 & -1.27 & $\begin{array}{l}-.10 \\
(.09)\end{array}$ & $-.07, .28$ & .25 & -1.16 & --- & --- & --- & --- & --- & --- & --- & --- \\
\hline Constant & $\begin{array}{l}-.00 \\
(.08)\end{array}$ & $-.18, .16$ & .92 & -.10 & $\begin{array}{l}-.01 \\
(.08)\end{array}$ & $-.17, .16$ & .93 & -.09 & $\begin{array}{l}-.02 \\
(.10)\end{array}$ & $-.22, .19$ & .86 & -.18 & $\begin{array}{l}-.02 \\
(.10)\end{array}$ & $-.23, .18$ & .83 & -.22 \\
\hline$F$ & & 9.61 & & & & 9.64 & & & & 7.46 & & & & 6.34 & & \\
\hline $\mathrm{R}^{2}$ & & .09 & & & & .11 & & & & .05 & & & & .06 & & \\
\hline$N$ & & 516 & & & & 516 & & & & 428 & & & & 428 & & \\
\hline
\end{tabular}

NOTE: Entries are unstandardized partial regression coefficients $(b)$ and robust standard errors in parentheses. 
Table 4

Compliance with the Law OLS Regression Models

\begin{tabular}{|c|c|c|c|c|c|c|c|c|c|c|c|c|c|c|c|c|}
\hline \multirow[t]{4}{*}{ Variables } & \multicolumn{16}{|c|}{ Compliance with the law } \\
\hline & \multicolumn{8}{|c|}{ US Sample } & \multicolumn{8}{|c|}{ Ghana Sample } \\
\hline & \multicolumn{4}{|c|}{ Model 1} & \multicolumn{4}{|c|}{ Model 2} & \multicolumn{4}{|c|}{ Model 3} & \multicolumn{4}{|c|}{ Model 4} \\
\hline & $\begin{array}{c}b \\
(S E)\end{array}$ & $95 \% \mathrm{CI}$ & $p$ & $t$ & $\begin{array}{c}b \\
(S E)\end{array}$ & $95 \% \mathrm{CI}$ & $p$ & $t$ & $\begin{array}{c}b \\
(S E)\end{array}$ & $95 \% \mathrm{CI}$ & $p$ & $t$ & $\begin{array}{c}b \\
(S E)\end{array}$ & $95 \% \mathrm{CI}$ & $p$ & $t$ \\
\hline Police legitimacy & $\begin{array}{c}.36 \\
(.05)\end{array}$ & $.26, .46$ & .00 & 7.17 & $\begin{array}{c}.23 \\
(.08)\end{array}$ & $.07, .39$ & .00 & 2.80 & $\begin{array}{c}.20 \\
(.09)\end{array}$ & $.01, .39$ & .04 & 2.12 & $\begin{array}{c}.15 \\
(.11)\end{array}$ & $-.06, .36$ & .17 & 1.38 \\
\hline Obligation to obey & -- & --- & --- & -- & $\begin{array}{c}.20 \\
(.09)\end{array}$ & $.02, .38$ & .03 & 2.14 & -- & -- & --- & -- & $\begin{array}{l}.11 \\
(.14)\end{array}$ & $-.16, .39$ & .42 & .82 \\
\hline Male & $\begin{array}{l}-.24 \\
(.08)\end{array}$ & $-.39,-.09$ & .00 & -3.17 & $\begin{array}{l}-.24 \\
(.08)\end{array}$ & $-.39,-.09$ & .00 & -3.15 & $\begin{array}{l}-.42 \\
(.10)\end{array}$ & $-.62,-.22$ & .00 & -4.20 & $\begin{array}{l}-.42 \\
(.10)\end{array}$ & $-.62,-.22$ & .00 & -4.20 \\
\hline Age & $\begin{array}{c}.03 \\
(.02)\end{array}$ & $-.00, .06$ & .09 & 1.71 & $\begin{array}{c}.03 \\
(.02)\end{array}$ & $-.00, .06$ & .08 & 1.75 & $\begin{array}{l}-.01 \\
(.03)\end{array}$ & $-.06, .04$ & .57 & -0.57 & $\begin{array}{l}-.01 \\
(.03)\end{array}$ & $-.06, .04$ & .60 & -.53 \\
\hline White & $\begin{array}{l}-.14 \\
(.08)\end{array}$ & $-.28, .01$ & .07 & -1.80 & $\begin{array}{l}-.15 \\
(.08)\end{array}$ & $-.30, .00$ & .05 & -1.95 & --- & --- & --- & --- & --- & --- & --- & --- \\
\hline Low self-control & $\begin{array}{l}-.05 \\
(.00)\end{array}$ & $-.06,-.04$ & .00 & -11.40 & $\begin{array}{l}-.05 \\
(.00)\end{array}$ & $-.05,-.04$ & .00 & -10.85 & $\begin{array}{l}-.03 \\
(.01)\end{array}$ & $-.04,-.02$ & .00 & -4.71 & $\begin{array}{l}-.03 \\
(.01)\end{array}$ & $-.04,-.01$ & .00 & -4.64 \\
\hline Constant & $\begin{array}{l}1.72 \\
(.16)\end{array}$ & $1.41,2.02$ & .00 & 11.08 & $\begin{array}{l}1.67 \\
(.16)\end{array}$ & $1.36,1.98$ & .00 & 10.58 & $\begin{array}{l}1.14 \\
(.21)\end{array}$ & $.73,1.54$ & .00 & 5.49 & $\begin{array}{l}1.12 \\
(.21)\end{array}$ & $.72,1.53$ & .00 & 5.43 \\
\hline$F$ & & 54.30 & & & & 45.72 & & & & 13.62 & & & & 11.19 & & \\
\hline $\mathrm{R}^{2}$ & & .33 & & & & .34 & & & & .11 & & & & .11 & & \\
\hline$N$ & & 516 & & & & 516 & & & & 428 & & & & 428 & & \\
\hline
\end{tabular}

NOTE: Entries are unstandardized partial regression coefficients $(b)$ and robust standard errors in parentheses. 
